\title{
MIGRATION, INEQUALITY AND EQUALITY \\ IN A GLOBALIZED WORLD: THE PARADOX OF REFRAMING THE NATION STATE*
}

\author{
Peter Nitschke
}

University of Vechta

\begin{abstract}
The article raises important issues associated with increasing social inequality and strengthening of intercountry and intercontinental migration flows in the global world. Special attention is paid to migrants from Africa and the socio-economic problems of Europe, where illiterate migrants cannot solve the problem of shortage of skilled workers. Social problems caused by migration processes have been analyzed, and it is concluded that the integration of immigrants in the European social system is not an administrative, but a complex cultural process that requires huge changes from both sides.
\end{abstract}

Keywords: global world, migration, state, integration, culture, inequality, national identity.

\section{The Effects of Migration in a Globalized World ${ }^{1}$}

In a globalized world, there is much evidence for the nation state to re-enforce the capacity in organizing the common goods for its own citizens. A lot of phenomena in global politics are a threat towards the capabilities of a welfare system which is traditionally bonded to the frame of a nation state. Not only because of the effects in the last two years, this problem has showed relevance to the question of migration for the European Union as a supranational system as well as for each member state. National solidarity seems to be deconstructed because of a universal approach of human rights. The question will be what kind of legitimacy the nation state may find his way back or what kind of new deal will be made in the near future relating to the incorporation of a large number of people coming from all over the world into the EU-system.

For Europe, especially the situation in Africa is relevant: about 20 million Africans are on refuge way, however, most of them are staying on the continent. Where they can escape from poverty is only the right next of the neighboring countries. It means that the migration is especially related to the territorial zones and neighbor states, which take place already on the bottom of the world hunger index. 'Always, when a large number of people flow a land, the pressure on the existing infrastructure goes up', comments an expert for development policy related to the situation in Africa (Sommerfeld 2016: 7). It brings in a snowball effect into African receiving countries. Also an increasing number of people migrate to Europe, however, most of them are only the people who can financially take care of themselves.

* The Russian translation was published in Vek globalizatsii [Век глобализации]. - 2017. - Num. 4. Pp. 92-99.

Journal of Globalization Studies, Vol. 10 No. 2, November $201937-44$

DOI: $10.30884 / j o g s / 2019.02 .03$ 


\section{The Attack on the Welfare State in Europe}

Since the beginning of 2015, about 1.33 Million people have come to Germany as a refugee or asylum seeker. Among them, about 960,000 applied for asylum until 2016 (Stocker 2016: 9). This is also approximately as same as the number of those who have been officially registered (after the deduction of double counted upon registration). In no case, however, all of them are going to get the asylum status. On the other hand, the rejection rate is over 90 percent! It means that most of them will either a) get only the restricted residence status or rather permitted status in the frame of the Refugee Convention of Geneva, or b) even could be banished and have to go back to their own countries!

Most refugees, who came to Germany since 2014, are in a working-age and often under 35 years old. Nevertheless, the unemployment rate among them is particularly high, concretely in early 2014 about 34,000 people from four lands were without job, and in 2016 there have been already 124,000 people officially! (Siems 2016a: 12). Four out of every five refugees, who are able to work, have no finished vocational training. Germany allows also the low-educated person to migrate, who stays more likely outside in the German economy which requires more and more educated degrees. This kind of immigration does not contribute to German economy, moreover certainly not to German social system at all. From the four core states, which are here related to the statistic, namely Syria, Eritrea, Iraq and Afghanistan, 65 percent of job seekers are still unemployed! (Ibid.)

Immigration is, first of all, an advantage for every open society basically. It benefits from newcomers in the medium or long term by innovative ideas, which not only stand on economic market, but also in the social field, like in the culture as a whole. In craft, it dominates in Germany, for instance, a considerable shortage in the occupation of free workplace. This demand does not cover easily, what is free in working places. Therefore, refugees seem to be welcome. The problem is, however, the high number of immigrants and their structural lack of qualification for the job market. Because of that, migrants and refugees who migrate to high wage countries, have a benefit, then and there, only when and where they also have the necessary level of education. Most of them, who came to Germany since 2015, are not in this case. Not only the numerous illiterates, who must first be familiar with the German language, produce intensively costs for the integration, but also the lowest qualified workers from Iraq, Syria or Afghanistan, could not be easily integrated into the German labor market. How far poorly qualified refugees make themselves felt positive or negative in the high wage labor market, has never been properly documented in the international research until now (q.v. also Greive and Kaiser 2015: 12). Here can be indicated a positive example from Miami in 1980's. When more than 100,000 refugees came from Cuba to Florida within a few months, the labor supply grew by seven per cent; however the wages for unskilled workers were not declined at the same time. Certainly, in this case, the Cuban exile community had integrated the new arrivals obviously quickly and effectively without any great aid organized by the state.

For the welfare state, migrants require expenditures and financial resources, which are necessary for other policies too, for instance the providing of education or the expanding of public transport. Also, the integration of refugees will be in an utterly complex and especially long term process. This is an enormous balancing act between the German population and the new immigrants: while the employment rate in the German 
society is about 60 per cent, but it is only about 11 per cent for the refugees and asylum seekers, despite of intensive care by the state job placement service. Nowadays (2016), the unemployment rate of refuges is 52 per cent, while it is only 6.1 per cent in the German population! (Stocker 2016: 9). This unbalance throws a burden on the German society, especially the welfare system. These structural effects are also quite similar in other EU member states. In this respect, the growing displeasure or resistance against the refugees are explained. They are considered as immigration into the social security system of the European states - and also they are!

The Dutch sociologist Ruud Koopmans, who teaches at the Humboldt University as a migration researcher, looks critically the current influx of refugees into the EU, because this mass immigration is carried out without any systematic choice by receiving societies and obviously it is not led to the conditions of the national labor market in the EU. Koopmans states that 'Muslims with assimilation to the majority society often harder to do than other migrant groups' (Siems 2016b: 8). What is the reason? Is it because of the pride (in true faith) or racist arrogance? Also, Koopmans skeptically evaluates the fundamentally and optimistically favored economic interpretation on the immigration from the EU-Commission (or also from the German government) (Ibid.): 'But not every art of immigration is useful for land. Some art of immigration even aggravates the problem of welfare states. Only when a migrant integrates into the labor market, the society profits from that'.

\section{Inequality and Equality in the Nation State}

Both sides, for instance the receiving society and the new arrivals, must consider the integration as an investment. It means that the receiving society is allowed to deal with the question of costs first of all. Then it is finally about their social integrity as a whole. It is not enough to stimulate and retrieve the juridical sorting machine, simply according to German administrative law. It is about more, namely the matter of meaning and purpose of social systems. Thus, it is necessary to debate newly on the limits of national solidarity and both inward and outward. The expectation of a billions Euros more which could already dominate integration, is also unrealistic and dangerous. The parallel societies from guest worker generations demonstrate not only in Germany, but also in France and the Netherlands that it is not done with a money distribution problem alone. Integration is, after all, not an administrative act, but a complex cultural process, which has required enormous changes on both sides.

It is poverty that drives people from the Near and Middle East to Europe. Their own regimes are incapable or unwilling, in order to solve the massive problem of social inequality. Entirely without any regard to the concrete civil war situation in Syria and Iraq, it is for them a hope for a better life, which bases the massive refugee influx. However, most people from the Arabic World came to Europe, not because of the Democratic Freedom rights. Consequently, the profound norm conflicts in EU-states with refugees are pre-programmed. A German-Syrian political scientist Bassam Tibi explains concretely in an interview the dignity principle of a male Muslim as follows (Seibel 2016: 8): 'A Muslim is allowed to live temporarily in a non-Islamic society. But, he is not allowed to join this society. In this way, many are educated'.

Tibi refers to his recent experience at the American University of Cairo: 'There is no democracy. It is not discussed. The policeman says which way people have to go. 
When these people come here and experience conciliatory, friendly policemen, they think that might be no policeman, but like a laughing stock. They do not feel free, but lost'. The immigrants have a fragile impression of their own position because the order is not prescribed as a real order. It symbolizes itself only in the form of uniform, but not in the necessary strictness of laws. This leads the immigrants to persistent norm conflicts.

Insofar, Tibi sees Merkel's decision in the late summer 2015 in an extremely critical view (Seibel 2016: 8):

This is not immigration similar to the case of America, where the qualified immigrants are chosen. Here, it is a demographic snow-slide that sloshes over us ... The thing has not yet been eaten. I was not in Egypt for ten years, and today there are 15 million more people since then. All want to come here, including university professors. I learned in Cameroon, in Senegal, in Nigeria, I know Africa very well. There is no single democracy in Black Africa. The poverty is growing. Over Libya it will be million and the problem of poverty, however, will not be solved.

In the EU receiving countries, it is possible to see in case of the help of former immigrant populations, how many difficulties they have with their integration over the past decades. Paradoxically, there is often a compartmentalization by migrants, when a particular familial environment moved to the immigration country. In Germany, this is especially related to Turkish guest workers (Siems 2016: 8): 'When the families moved and built up communities themselves, the men change from the status of modern men suddenly to conservative family fathers'.

\section{Reframing National Identity}

Meanwhile, a kind of anti-movement towards migration is obviously growing in the EU Member States. Not least, the Brexit was successfully decided on these questions, from the perspective of its supporters. However, this kind of position can be seen also worldwide: from Trump's election in the USA, the position of the Australian government against refugees migrated by boat, and to the refusal of the emigration movement of Muslim minority from Myanmar from the neighboring states (inclusive Bangladesh), it can be observed a change in the migration problem everywhere. As an elderly Turkish demonstrator told a reporter in front of TV camera, when the demonstration in the portand tourist city, Dikili, against the resentment of Arab and Afghan refugees from Greece was discussed: 'I don't want the refugees because my life is the first' (VideoReportage 2016). In this kind of atmosphere, the behavior is prevalent, which could be seen as a return to national states. Of all things, the nation state which has been historically depreciated as a faded model in the frame of discussion about globalization, and now it turns out to be a decisive model for the near future. That is a paradox, because the effects of massive migration could not be handled and much less wisely managed through an (often small) nation state itself.

Basically, there is also a symptom, which was already crystallized by Samuel Huntington in his remarkable article in Foreign Affairs (1993). The new world paradigm of Clash of Civilizations, it is not only dedicated on the confrontation of cultural conceptions within the civilizing scale, but also in a process of re-consciousness, which is indi- 
cated by Huntington as an Indigenization at that time. According to him, it means a reorientation related to norms and cultural values, which could be observed in states particularly, where there is no core of identity formulated substantially in the frame of Modern, specifically here: The Globalization - and is thus actually a form of reindigenization (Huntington 1993: 22-49, 2002; Nitschke 2014: 13-44). Back to the roots is the wake-up call for all people, who feel that they are overwhelmed by the globalization and misunderstood or not any more represented by their national elite. Obviously the indigenization works as a dialectical process within globalization and leads the states of the First World in the way, where the particular nation state as a social and welfare system should be defended through all means against strangers, who come into the country. In the present, we are watching that the re-orientation toward national solidarity has become a tension constellation for a national system of social security. Parties and associations are almost disrupted by the question, whether we should be obligated for a universal solidarity in the context of human rights, or whether it can be practiced only under the agenda of the nation state? The latter would mean also a targeted blocking for welfare systems of the First World against the massive immigration from the Third World. In USA as the classical country for immigration until now, it can be observed, where the great number of immigration, basically goes to, especially when it is also illegally successful. In the national society, there are changes in its demographic condition. This has effects on everything, especially also on the preferences for parties in national elections. While Hispanics, for example, were only about 5 per cent of US population in the 1980's, the rate of them in the total population has been already more than 15 per cent since the end of the first decade of the $21^{\text {st }}$ century! (Kurth 2016: 13-54) Thus, national policy also changes in its basic orientation: about 70 per cent of Hispanics voted for Obama in 2008 (q.v. Ibid.: 42). It is undoubtedly one of the deeper reasons of the choice for Donald Trump. The stronger and clearer the social effects of multiculturalism are perceived in the states of the First World as financial burdens, the consensus problem of social justice especially in the welfare state regimes becomes particularly more sharpened. The Clash of Civilizations is then no longer a clash, but it has mutated into a diffuse form of social, economic and, most of all, also cultural contradictions (Nitschke 2016: 12-14), which discourage all the capacity of the community in the sense of national solidarity.

The overstraining of welfare state leads to a legitimation crisis of the national system in turn: universality (of human rights) and national sovereignty are in an unsolvable conflict here. The so called populist movement, which becomes much stronger everywhere in the democratic countries, is, not different from neo-nationalist formations of the middle classes (or parts of it), who feels that they have been left behind by the political establishment which cannot understand their interests anymore. If international NGOs declare the refugees as propagandistic new people, who are allowed to go everywhere and take what they are entitled as human being, then the citizen as a taxpayer wonders why he (or she) should support such kind of universalistic policy? - There is, after all, no such thing like global equality (Corry 2013).

\section{Walls and Open Societies in Europe}

The call for walls or blocking the migration is insofar a logical consequence which comes from a civic consciousness. In this perspective, the whole benefits which result 
from the working class has to be controlled and accommodated in the frame of national order but not towards a universal agenda. Also, the EU is not able to provide a truly satisfied organizational structure as supranational power, because they do not have any authority over relevant functions and institutions. Let us take the example of security of the EU's external borders in the Mediterranean:

According to the assessment of Ms. Federica Mogherini, Italian high-representative of the Union for Foreign Affairs and Security Policy, only in Libya alone, there are about 500,000 refugees and migrants in the starting position, in order to cross over the Mediterranean Sea by ship or boat (q.v. Posener 2016: 3). Mogherini regards that the efforts of European Mediterranean-Mission Sophia are successful; already 60 human traffickers were arrested and 100 human trafficking boats were destroyed - in six months! That seems to be like a joke because it is about 10 human traffickers per month. After all, about 13,000 people who were in distress at sea were rescued. Sophia retrieves the burden of the conscience of European simply, but no more than that. In the face of the challenge of massive immigration, which is considered as a threat to the social balance in the EU states, Sophia gives no answer. After all, Mogherini also states (Ibid.): 'We, Europeans, ultimately have to consider the mass movement of people as a phenomenon of our times. We will not be able to stop the migration also into Europe, but it can be overcome'. The question is however - what is the right way?

Is multilateralism the answer here? Definitely, the refugees - or rather migration problems are too huge to be satisfactorily solved by one nation state alone. In this respect, it is generally agreed that the EU states reach an agreement about the common supranational conception. With Schengen I, II, III and the regulations of Dublin I, II and $I I I$, the EU seems to be already on the right way. However, we have seen in the recent past, this kind of construction is not working - or strictly speaking: only as long as there was no massive immigration. However, this will be the permanent task for Europe in the coming years. Europe is regarded by many people, especially in Africa, southern parts beyond the Sahara, as the Promised Land, an art of Eutopia. Insofar, a new realism must be introduced in considering the migration phenomenon. This realism refers to the conditions in the national states itself. Here, it should be necessary to differentiate clearly between the rhetoric of supra-nationalism by idealists and the real structures and possibilities in the individual member states. The president of Council on Foreign Relations states as follows (Haass 2016: 2): 'The political reality is sure enough that the most of governments are not ready to undertake to receive a certain number of refugees or a concrete share of the refugee population'. The UN also fundamentally fails, because they only lead a rhetorical debate (Haass 2016: 2): 'We will hear a lot of talk in New York. However, the cold truth is that there exists only a little bit of communion on an international level. As long as it is so, millions of men, women and children will be exposed to the dangerous present and bleak prospects for the future'.

What is to be done now? In practice, the EU should have to formulate a consistent nomenclature for the right of asylum - and this should be applied by every nation state in the EU! However, it would mean that Germany revises newly its historical singular version for the right of asylum in the form of provision of German Basic Law (article 16-a), and adapts it to EU standards. The EU regulations and the German Basic Law, both are not suitable anymore for the current dimension, because those perspectives 
came from the times, when the wave of refugees and immigrants for working had never been considered in the current situation. Also the belief that refugees re-migrate to their homeland when the war is over, is almost unrealistic in consideration of the nowadays life standard with the enormous possibilities in consumption in the First World.

What can the EU do in the actual constellation? It is certainly not enough that some Member States draw borders, such as the countries on the Balkan-route in 2015 and 2016. Basically, a go-forward strategy is needed for the EU. They have to secure the territorial zone along with their external borders better than now. To increase the border guard agency Frontex with 2,000 officers only, is not enough. In order to make the EU external border secure, 100 times more border policeman would be required (if the EU should act as a supranational system)! An advance defense strategy against irregular massive immigration has to consider now the very Near and Middle East across the Mediterranean. It means more aid for development, but also a specific policy of security by the police in the name of all EU-Member States. Insofar, it has to be remembered that the plan, which was introduced by the German minister Otto Schily (as the minister for Inner Security in 2004) at that time, is actually still effective, or rather, more than ever. According to Schily's conception, the EU should establish various regional reception centers for intending immigrants and political refugees in the Arabic neighboringcountries of the Mediterranean area (Posener 2016: 3). As it is generally known, nothing came from the plan either. Since then, many things have been happening, only there are no right concepts for the prevention of migration from the African countries. For twelve years, the inactivity of the EU, particularly 11 years of that period under the responsibility of Chancellor Merkel in Germany!

Those circumstances, which are now considered once again from the side of the Angela Merkel's party this time, demonstrate the entire helplessness and previous ignorance: Africa can be saved in Africa only. But, for that, Europeans must be ready to do something. Only with benevolence and a little bit of charity, it will not be enough. And, to let the people simply come to Europe and to throw the social system into an unpayable situation is not the right answer either. This shows once again the principle of globalization: the dynamic structure shifting does not wait for politicians, who stay still in yesterday, because, yesterday, in fact, was already the day before and before yesterday.

\section{NOTE}

${ }^{1}$ This text was translated by Seul A. Lee, MA (University of Vechta), who did a fine and helpful interpretation toward the various versions in German during the genesis of the manuscript.

\section{REFERENCES}

Corry, O. 2013. Constructing a Global Polity. Theory, Discourse and Governance. New York. Greive, M., and Kaiser, T. 2015. So beeinflussen Flüchtlinge die Löhne. Die Welt (Oktober 7). Haass, R. N. 2016. UN versagt in der Flüchtlingsfrage. Die Welt (August 19). Huntington, S. P. 1993. The Clash of Civilizations? Foreign Affairs 72 (3): 22-49. Huntington, S. P. 2002. Kampf der Kulturen. Die Neugestaltung der Weltpolitik im 21. Jahrhundert. München.

Kurth, J. R. 2016. A History of Inherent Contradictions - The Origins and End of American 
Conservatism. In Levinson, S. V., Parker, J., and Williams, M. S. (eds.), American Conservatism (pp. 13-54). New York: Nomos, LVI.

Nitschke, P. 2014. Zivilisationskonflikte - Samuel P. Huntingtons 'Clash of Civilizations' in der Retroperspektive. Der Prozess der Zivilisationen - 20 Jahre nach Huntington. In Nitschke, P. (ed.), Analysen für das 21. Jahrhundert (pp. 13-44). Berlin.

Nitschke, P. 2016. Die Diffusion der Zivilisationen. Wissenschaft und Frieden 34 (4): 12-14.

Posener, A. 2016. Gute Idee, aber zu spät. Die Welt (November 15).

Seibel, A. 2016. Sehnsucht nach Heimat. Die Welt (Juli 4).

Siems, D. 2016a. Flüchtlingswelle erreicht den Arbeitsmarkt. Die Welt (Juli 1).

Siems, D. 2016b. Wir brauchen strenge Regeln. Die Welt (Juli 8).

Sommerfeld, F. 2016. Wirklich Arme fliehen selten nach Europa. Die Welt (Oktober 12).

Stocker, F. 2016. Einerseits, andererseits. Die Welt (August 27).

Video-Reportage Die Welt. 2016. Available at: http://www.welt.de/politik/ausland/article15 3942875/Ich-will-die-Fluechtlinge-nicht-mein-Leben-geht-vor.html, loaded on 13th of April 2016. 